\title{
Rhodothermus marinus, gen. nov., sp. nov., a Thermophilic, Halophilic Bacterium from Submarine Hot Springs in Iceland
}

\author{
By GUDNI A. ALFREDSSON, ${ }^{*}$ JAKOB K. KRISTJANSSON,${ }^{+}$ \\ SIGRIDUR HJÖRLEIFSDOTTIR ${ }^{1}$ AND KARL O. STETTER ${ }^{2}$ \\ ${ }^{1}$ Institute of Biology. University of Iceland, IS-108 Reykjacik, Iceland \\ ${ }^{2}$ Lehrstuhl für Mikrobiologie, Universität Regenshurg, D-8400 Regensburg, FRG
}

(Received 2 September 1987; revised 14 October 1987)

\begin{abstract}
Thermophilic, reddish-coloured heterotrophic bacteria different from Thermus were isolated from submarine alkaline hot springs in Iceland. The bacteria were obligately aerobic, moderately halophilic, Gram-negative rods, about $0.5 \mu \mathrm{m}$ in diameter and $2-2.5 \mu \mathrm{m}$ long. Neither spores, flagella nor lipid granules were observed, but a slime capsule was formed on carbohydrate-rich medium. Optimum growth was at $65^{\circ} \mathrm{C}, \mathrm{pH} 7 \cdot 0$, and at about $2 \%(\mathrm{w} / \mathrm{v}) \mathrm{NaCl}$. The bacteria were oxidase negative, catalase positive and contained a carotenoid pigment with the main absorbance peak at $476 \mathrm{~nm}$ and shoulders at 456 and $502 \mathrm{~nm}$. The GC content of the DNA was about $64 \mathrm{~mol} \%$. Electron micrographs clearly showed an outer membrane, about $9 \mathrm{~nm}$ thick, and the cytoplasmic membrane together with the peptidoglycan layer was about $14 \mathrm{~nm}$ in thickness. The isolates were nutritionally different from Thermus. They utilized several common sugars but glutamate and aspartate were the only amino acids that most strains used. These bacteria are considered to represent a new genus which we name Rhodothermus, with the type species Rhodothermus marinus.
\end{abstract}

\section{INTRODUCTION}

In recent years there has been much interest in organisms which are associated with submarine hot springs (Corliss \& Ballard, 1977; Jannasch \& Nelson, 1984; Stetter, 1985). Most of the work has been done on the deep-sea hydrothermal vents in the Pacific Ocean, which support extensive populations of certain invertebrates and bacteria, including some thermophiles (Corliss \& Ballard, 1977; Jannasch \& Nelson, 1984). The best-known thermophilic submarine bacterium is Pyrodictium, isolated by Stetter $(1982,1985)$ from a shallow-water solfatara field in Italy.

In a recent study of submarine alkaline hot springs in Iceland we isolated salt-tolerant strains of Thermus (Kristjansson \& Alfredsson, 1986; Kristjansson et al., 1986). The halotolerant Thermus strains were very similar to their terrestrial counterparts, except in being adapted to the submarine thermal environment (Kristjansson et al., 1986). Bacteria of the genus Thermus are the most common heterotrophs in terrestrial alkaline hot springs (Kristjansson \& Alfredsson, 1983; Kristjansson et al., 1985), and this also seems to be the case for submarine alkaline hot springs. There is a great diversity among strains of Thermus (Alfredsson et al., 1985; Hudson et al., 1986; Munster et al., 1986) but only two species have so far been validly described (Brock, 1984; Loginova et al., 1984). The only other aerobic thermophilic heterotrophs known to grow in alkaline hot springs at $70-80^{\circ} \mathrm{C}$ are Thermomicrobium roseum (Jackson et al., 1973) and several species of sporeformers (Kristjansson \& Alfredsson, 1983).

In this paper we describe the isolation and characterization of a thermophilic and halophilic bacterium from shallow-water submarine hot springs in Iceland which differs substantially

† Present address: Biotechnology Laboratory, Icelandic Technology Institute, IS-112 Reykjavik, Iceland. 
from strains of Thermus sp., Thermus ruber (Loginova et al., 1984) and Thermomicrobium (Ramaley \& Hixson, 1970). The new isolates are considered to represent a new genus and species of thermophilic bacteria, for which we propose the name Rhodothermus marinus.

\section{METHODS}

Study site. The hot springs are located off the coast of a small peninsula, Reykjanes, in the Isafjardardjup Bay, NW Iceland. A series of alkaline hot springs is located on the peninsula itself and down to sealevel. In a small inlet called Hveravik at the tip of the peninsula, several hot springs occur from a few to about 100 metres off the coast. In the inlet several hot springs emerge at low tide, but others are located further out, at a depth of 2-3 metres at low tide. The samples used in this study were taken from these outermost springs. The water in the hot springs is alkaline, and of low sulphide content, but slightly mixed with seawater (chloride 600 p.p.m.). The temperature in the hot-water duct ranges from 75 to $95^{\circ} \mathrm{C}$ in different springs.

Sampling. The samples were collected by diving as previously described (Kristjansson et al., 1986; Stetter, 1982). Samples were collected directly from the openings of five different submarine hot springs at a depth of 2-3 metres. It was not possible to exclude seawater completely when sampling. The samples, which consisted of fine gravel and water, were kept refrigerated until processed further.

Isolation of bacteria. Water samples were filtered directly but sand and gravel samples were washed with sterile seawater, which was then filtered through Millipore membrane filters with a pore size of $0.45 \mu \mathrm{m}$. The filters were put on plates containing nutrient agar medium 162 of Degryse et al. (1978) containing $3 \%(\mathrm{w} / \mathrm{v}) \mathrm{NaCl}$ and incubated at $72{ }^{\circ} \mathrm{C}$ for $4 \mathrm{~d}$ (Kristjansson \& Alfredsson, 1983). Red-pigmented colonies were picked and purified by streaking onto the same medium. Twenty-one strains, designated R-1 to R-21, were used for this study. All the strains were taken through the identification tests used for identification of Thermus spp. (Brock, 1984; Degryse et al., 1978; Kristjansson \& Alfredsson, 1983).

Media and culture conditions. The bacteria were routinely cultured on nutrient agar medium 162 containing $1 \%$ $(w / v) ~ N a C l$ but other concentrations of $\mathrm{NaCl}$ were used when appropriate. Strains were grown at a variety of temperatures, $\mathrm{pH}$ values and concentrations of $\mathrm{NaCl}$ in order to determine their basic physiological characteristics. Growth on single carbon sources was tested on minimal-agar plates inoculated with a multipoint inoculator as previously described (Alfredsson et al., 1985). All growth tests were done at $65^{\circ} \mathrm{C}$. Growth on agar was scored positive if clearly visible and confluent growth had occurred after $7 \mathrm{~d}$ incubation and if the strain grew again upon subculturing onto the same medium. In liquid medium, growth was followed by measuring the increase in $\mathrm{OD}_{660}$ in a Hitachi spectrophotometer, model UV/VIS 100-20.

Electron microscopy. The cells were grown overnight on agar, scraped off and fixed with $3 \%(\mathrm{w} / \mathrm{v})$ glutaraldehyde in $0.1 \mathrm{M}$-cacodylate buffer $\mathrm{pH} 7.4$ (Ericsson et al., 1978), then centrifuged for $10 \mathrm{~min}$ at $8000 \mathrm{~g}$. The pellet was postfixed with $2 \%(\mathrm{w} / \mathrm{v}) \mathrm{OsO}_{4}$ in the same buffer, dehydrated with ethanol and embedded in Spurr resin. Ultrathin sections were cut with a Reichert ultramicrotome Om U3. The sections were stained in $2 \%(\mathrm{w} / \mathrm{v})$ aqueous uranyl acetate for $20 \mathrm{~min}$ and in Reynolds' lead citrate for $5 \mathrm{~min}$ (Hayat, 1970). The electron micrographs were taken with a Philips EM 300 electron microscope $(80 \mathrm{kV})$ by Johann Arnfinnsson, Department of Anatomy, University of Iceland.

DNA base composition. DNA was prepared according to Lauerer et al. (1986). The GC content of the DNA was calculated from the melting point in 0.1 $\times$ SSC (Marmur \& Doty, 1962), using calf thymus DNA ( $42 \mathrm{~mol} \% \mathrm{GC}$ ) as a reference. Direct analysis of the DNA base composition was done by HPLC chromatography after digestion of the DNA with nuclease P1 (Zillig et al., 1980).

Determination of antibiotic sensitivity. Sensitivity to the following antibiotics was tested (the amount per disc is given in parenthesis): penicillin G (10 IU), ampicillin $(10 \mu \mathrm{g})$, streptomycin $(10 \mu \mathrm{g})$, kanamycin $(30 \mu \mathrm{g})$, gentamicin $(10 \mu \mathrm{g})$, tetracycline $(30 \mu \mathrm{g})$, chloramphenicol $(30 \mu \mathrm{g})$, erythromycin $(15 \mu \mathrm{g})$, polymyxin B (300 units), bacitracin $(0 \cdot 1$ unit), nalidixic acid $(30 \mu \mathrm{g})$, vancomycin $(70 \mu \mathrm{g})$, lincomycin $(19 \mu \mathrm{g})$, rifamycins $(30 \mu \mathrm{g})$ and virginamycin $(30 \mu \mathrm{g})$. The discs were standard $6 \mathrm{~mm}$ antibiotic discs except for vancomycin, lincomycin, rifamycins and virginamycin which were applied in $10 \mathrm{~mm}$ discs. These four antibiotics were from ROSCO Diagnostica, Denmark, bacitracin was from Mast Laboratories, and all the other antibiotics were from Oxoid. Bacteria were grown on nutrient agar medium 162 containing $1 \%(\mathrm{w} / \mathrm{v}) \mathrm{NaCl}$ and the results scored after overnight growth at $65^{\circ} \mathrm{C}$. Antibiotic sensitivities of Thermus strains were determined on the same medium without added $\mathrm{NaCl}$. No detectable inhibition was scored as $6 \mathrm{~mm}$ and $10 \mathrm{~mm}$ for the two different disc sizes. To check whether the absence or presence of $\mathrm{NaCl}$ affected the size of the inhibition zone, the antibiotic sensitivity of a salt-tolerant Thermus strain, IB-21 (Kristjansson et al., 1986) was tested on standard nutrient agar medium 162 and on the same medium containing $1 \%(\mathrm{w} / \mathrm{v}) \mathrm{NaCl}$.

Spectrophotometry of pigments. For determination of the carotenoid pigments the bacteria were extracted with $90 \%(\mathrm{w} / \mathrm{v})$ acetone as described by Brock \& Brock (1967). After centrifugation the clear supernatant was taken and the absorption spectrum determined in a Perkin Elmer 550-S spectrophotometer. 
RESULTS

Isolation. As a part of our studies on Thermus spp. from submarine hot springs, media containing varying concentrations of $\mathrm{NaCl}$ from 0 to $5 \%(\mathrm{w} / \mathrm{v})$ were employed. With no added $\mathrm{NaCl}$ only yellow-pigmented colonies of Thermus were isolated. When $1 \% \mathrm{NaCl}$ or more was added both yellow- and red-pigmented colonies appeared on the filters. The proportion of the red-pigmented colonies increased with increasing $\mathrm{NaCl}$ concentration up to $2 \%(\mathrm{w} / \mathrm{v})$.

Morphology and pigments. On the nutrient medium 162 and at $65^{\circ} \mathrm{C}$, these bacteria formed reddish-coloured, low-convex colonies, $3-4 \mathrm{~mm}$ in diameter and with an entire edge. All strains were Gram-negative rods, normally about $0.5 \mu \mathrm{m}$ in diameter and about $2-2.5 \mu \mathrm{m}$ long. Filaments were never observed and neither spores, flagella nor lipid inclusions were seen by conventional staining methods or in the electron micrographs. When the bacteria were grown on carbohydrate-rich medium a distinct capsule was formed, as demonstrated by the India ink method. Electron micrographs of thin sections showed a normal Gram-negative cell envelope (Fig. 1). An outer membrane, about $9 \mathrm{~nm}$ thick, was clearly visible and the cytoplasmic membrane together with the peptidoglycan layer was about $14 \mathrm{~nm}$ in thickness.

Acetone extracts showed a spectrum typical of a carotenoid pigment with the maximum at $476 \mathrm{~nm}$ and shoulders at 456 and $502 \mathrm{~nm}$. For Thermus ruber the maximum is at $483 \mathrm{~nm}$, with shoulders at 455 and $513 \mathrm{~nm}$ (Loginova \& Egorova, 1975; Loginova et al., 1984); for Thermus aquaticus YT-1 the main peak is at $451 \mathrm{~nm}$ and the shoulders at 428 and $475 \mathrm{~nm}$ (Brock, 1978).

Physiological properties. The 21 reddish-coloured isolates were all very similar physiologically. Optimum growth temperature was $65^{\circ} \mathrm{C}$ and optimum $\mathrm{pH}$ was 7.0. Minimum and maximum growth temperatures were about $54^{\circ} \mathrm{C}$ and about $77^{\circ} \mathrm{C}$, respectively. None of the strains grew unless $\mathrm{NaCl}$ was present in the medium and adaptation to medium lacking $\mathrm{NaCl}$ was not possible (Kristjansson et al., 1986). The optimum $\mathrm{NaCl}$ concentration for growth of strain $\mathrm{R}-10$ in liquid culture medium 162 was about $2 \%(\mathrm{w} / \mathrm{v})$ and the maximum above $6 \%(\mathrm{w} / \mathrm{v})$ (Fig. 2$)$. This was also shown to be true for all the other new isolates grown on solid medium. In contrast, the type strain Thermus aquaticus grows optimally without $\mathrm{NaCl}$ and shows a very low $\mathrm{NaCl}$ tolerance (Fig. 2). The same is true for Thermus ruber (Table 1). On plates the growth of the new isolates was much reduced at $5 \%(\mathrm{w} / \mathrm{v}) \mathrm{NaCl}$ and only 6 of the 21 strains showed marginal growth at $6 \%(\mathrm{w} / \mathrm{v}) \mathrm{NaCl}$. The maximum specific growth rate $(\mu)$ in nutrient medium 162 with $1 \%(\mathrm{w} / \mathrm{v}) \mathrm{NaCl}$ was $0.5 \mathrm{~h}^{-1}$. All the strains were catalase positive but oxidase negative and did not hydrolyse casein. No nitrate reduction was detected. The bacteria did not grow anaerobically in nutrient salt medium $162(1 \%, \mathrm{w} / \mathrm{v}, \mathrm{NaCl})$ and did not ferment sugars anaerobically.

The bacteria grew on minimal medium plates with several single compounds added as sole carbon and energy source. Their growth pattern on these single carbon sources was very different from that of strains of Thermus. Twenty strains were tested on 32 different compounds. The following compounds were used by most of the strains tested (the percentage of strains showing good or distinct growth is given in parenthesis): L-aspartate (100), L-glutamate (95), gelatin (100), acetate (60), pyruvate (100), glucose (70), galactose (75), starch (100), sucrose (95), lactose (95), raffinose (95) and maltose (85). The substrates not utilized by any of the 20 strains were: L-arginine, L-asparagine, L-glutamine, L-leucine, L-phenylalanine, L-proline, L-serine, Lthreonine, L-valine, butyrate, gluconate, fumarate, malate, succinate, 2-oxoglutarate, citrate, sorbitol and glycerol. On DL-alanine and L-ornithine growth occurred only as a few wellseparated colonies. This phenomenon has also been observed with Thermus, when the colonies were found to be mutants (Alfredsson et al., 1985).

All organic acids tested were supplied as sodium salts, except butyric acid and malic acid (Alfredsson et al., 1985). A high percentage of the strains grew well on several sugars, but of the amino acids tested only aspartate and glutamate were utilized.

DNA base composition. The GC content of DNA was determined for two strains, R-10 $(64.4 \mathrm{~mol} \%)$ and R-18 (64.7 mol \%). Preliminary results from sequencing of $16 \mathrm{~S}$ ribosomal RNA of strain R-10 showed that it was not related to Thermus X-1 (Ramaley \& Hixson, 1970) or to 

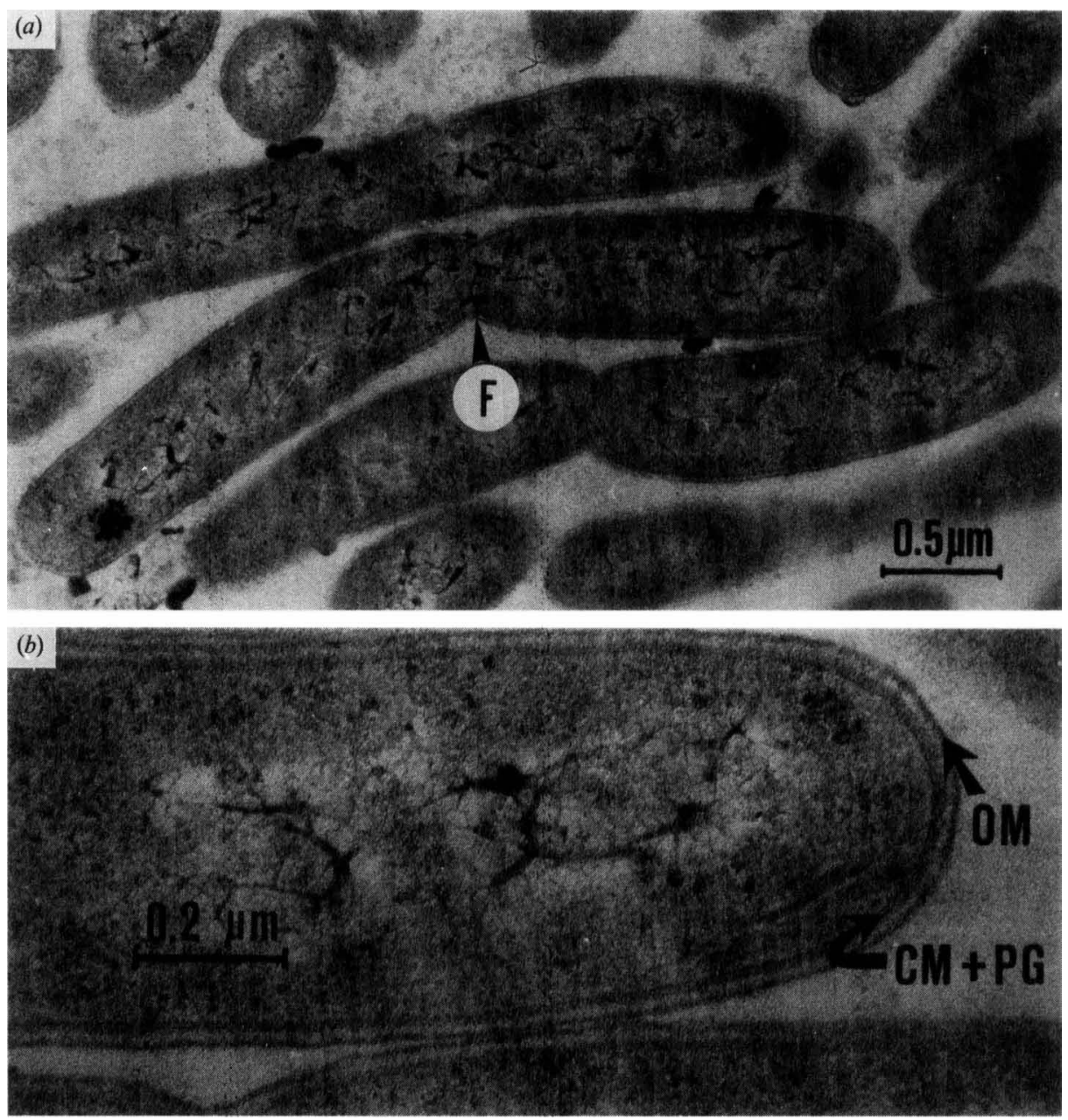

Fig. 1. Electron micrographs of Rhodothermus marinus strain R-18. (a) Thin longitudinal and crosssections showing the width and length of typical cells as well as dividing cells with furrowing $(F)$. (b) The cell envelope, consisting of a cytoplasmic membrane plus peptidoglycan layer (CM + PG), and a wellseparated outer membrane (OM).

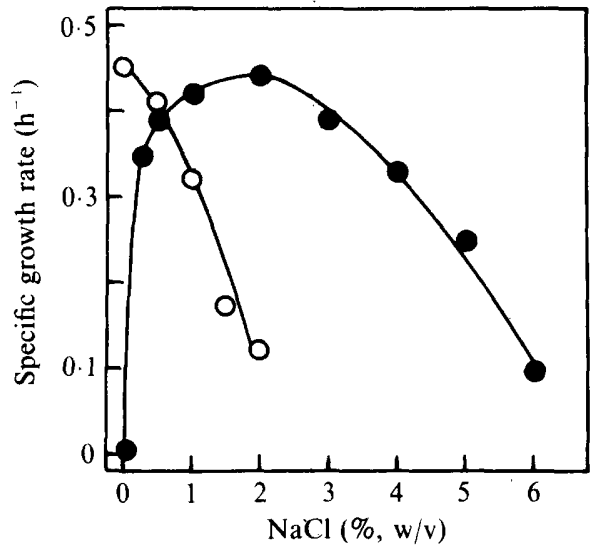

Fig. 2. Growth rate in nutrient medium 162 as a function of $\mathrm{NaCl}$ concentration in the medium. Growth temperature was $65^{\circ} \mathrm{C}$. O, Thermus aquaticus strain YT-1;, Rhodothermus marinus strain R-10. 
Table 1. Main characters differentiating the new genus Rhodothermus from the genera Thermus and Thermomicrobium

\begin{tabular}{|c|c|c|c|c|}
\hline Character & Rhodothermus & Thermus & $\begin{array}{l}\text { Thermus } \\
\text { ruber* }\end{array}$ & Thermomicrobium $\dagger$ \\
\hline Cell length, $\mu \mathrm{m}$ & $2-2 \cdot 5$ & $5-10$ & $3-6$ & $3-6$ \\
\hline Chains or filaments & - & + & + & - \\
\hline Slime capsule & + & - & $-\ddagger$ & - \\
\hline 'Rotund bodies' & - & + & $+\S$ & - \\
\hline Colony colour & Reddish & Yellow/orange & Red $\ddagger$ & Red \\
\hline Main carotenoid peak & $476 \mathrm{~nm}$ & $451-456 \mathrm{~nm}$ & $483 \mathrm{~nm} \ddagger$ & $494 \mathrm{~nm}$ \\
\hline Nitrate reduction & - & + & $-\ddagger$ & \\
\hline Oxidase reaction & - & + & $+\ddagger$ & \\
\hline Exoprotease & - & Generally + & $+\ddagger$ & \\
\hline \multicolumn{5}{|l|}{ Growth in $\mathrm{NaCl}$ : } \\
\hline $0 \%$ & - & + & $+\ddagger$ & + \\
\hline $3 \%(w / v)$ & + & - & $-\ddagger$ & - \\
\hline $6 \%(w / v)$ & + & - & $-\ddagger$ & - \\
\hline \multicolumn{5}{|l|}{ Growth on: } \\
\hline Glucose & + & Rare & + & - \\
\hline Galactose & + & Variable & + & \\
\hline 2-Oxoglutarate & - & + & $-\ddagger$ & \\
\hline Glutamine & - & + & $-\ddagger$ & + \\
\hline Proline & - & + & $-\ddagger$ & \\
\hline \multicolumn{5}{|l|}{ Aminoglycoside } \\
\hline antibiotics & Resistant & Sensitive & Sensitive $\ddagger$ & Sensitive \\
\hline Temp. optimum $\left({ }^{\circ} \mathrm{C}\right)$ & 65 & $70-75$ & 60 & $70-75$ \\
\hline Generation time & $80 \min$ & $20-60 \mathrm{~min}$ & $60 \mathrm{~min}$ & $5.5 \mathrm{~h}$ \\
\hline
\end{tabular}

other bacteria with available 16S rRNA sequences (Olafur S. Andresson, personal communication).

Antibiotic resistance patterns. The antibiotic inhibition zone diameters for Thermus ruber, Thermus aquaticus (YT-1) and eight Icelandic Thermus strains were all very similar to each other. The new isolates tested, R-10 and R-18, gave a pattern of results much like these Thermus strains, except in being resistant to the aminoglycosides streptomycin, kanamycin and gentamicin. For strain R-10, the diameters of the inhibition zones (mm) were as follows: penicillin G, 68; ampicillin, 65; streptomycin, 8; kanamycin, 6 ; gentamicin, 6 ; tetracycline, 30 ; chloramphenicol, 28; erythromycin, 53 ; polymyxin $\mathrm{B}, 11$; bacitracin, 6 ; nalidixic acid, 6 ; vancomycin, 40 ; lincomycin, $>70$; rifamycins, 37; and virginamycin, 44 . The Thermus strains showed inhibition zones of about 30,23 and $32 \mathrm{~mm}$ for streptomycin, kanamycin and gentamicin, respectively. The control strain IB- 21 gave identical resistance patterns on media with and without $1 \%(\mathrm{w} / \mathrm{v}) \mathrm{NaCl}$.

Comparison of the new isolates with other bacteria. The new isolates were compared with other known Gram-negative, aerobic, thermophilic heterotrophs, namely Thermus aquaticus (Brock, 1984), Thermus ruber (Loginova et al., 1984) and Thermomicrobium (Jackson et al., 1973). The main features of these bacteria are listed in Table 1 and compared with the new isolates (Rhodothermus). Many of the previously reported characterization tests were repeated for $T$. ruber and some new ones added (Table 1). We found $T$. ruber to produce exoprotease although it had previously been reported not to peptonize milk (Loginova et al., 1984). In all other cases there was good agreement between our results and published data for $T$. ruber. 


\section{DISCUSSION}

The 21 strains reported here were all isolated from the same submarine geothermal area in Iceland (Kristjansson et al., 1986). Attempts to isolate them from other submarine hot springs in Iceland have not been successful (unpublished results). The isolates form a very homogeneous group, with only slight differences between strains in utilization of single carbon sources.

These new thermophilic bacteria have a temperature range for growth of about $54-77^{\circ} \mathrm{C}$ and an optimum growth temperature of about $65^{\circ} \mathrm{C}$. This means that they can only grow very close to the openings of the submarine hot springs: only a few centimeters from the openings the water would be too cold for growth. Normally, geothermal water is anaerobic until it emerges from the ground or seabed and absorbs oxygen from its surroundings. These bacteria are obligate aerobes, and are thus confined to a very narrow zone near the openings of the hot springs where both the temperature and oxygen content of the water are suitable for growth. As these bacteria are heterotrophs they must also utilize the organic material present in the seawater. The optimum $\mathrm{NaCl}$ concentration for growth of strain $\mathrm{R}-10$ in liquid culture was about $2 \%(\mathrm{w} / \mathrm{v})$ and the maximum above $6 \%(\mathrm{w} / \mathrm{v})$ (Fig. 2). These bacteria can therefore be considered as slightly halophilic or possibly moderately halophilic (Kushner, 1978; Russell \& Kogut, 1985). Their requirement for oxygen, $\mathrm{NaCl}$, organic material and temperature strictly defines a very narrow niche for these organisms in the hot spring ecosystem.

At present there are only two validly described species of the genus Thermus, i.e. Thermus aquaticus and Thermus ruber (Brock, 1984; Loginova et al., 1984), but many strains have been isolated from different places and sources (Brock, 1978; Egorova \& Loginova, 1975; Hudson et al., 1986; Munster et al., 1986; Oshima \& Imahori, 1974; Pask-Hughes \& Williams, 1977). Variations in optimum growth temperature, pigmentation, and nutrition have been reported among Thermus isolates (Alfredsson et al., 1985; Degryse et al., 1978; Loginova et al., 1984; Pask-Hughes \& Williams, 1977) and these differences are probably sufficient to warrant dividing the genus up into several species and possibly into more than one genus (Alfredsson et al., 1985; Hudson et al., 1986; Munster et al., 1986).

Thermus ruber forms red colonies similar to our new isolates, so we made a careful comparison between this species and the new isolates. Many reported characterization tests were repeated for Thermus ruber and some new ones added (Table 1), and as expected, they showed it to belong to the Thermus group (Hensel et al., 1986; Munster et al., 1986). This is seen from important features like the cell size, the oxidase reaction, the sensitivity to aminoglycoside antibiotics and the effects of $\mathrm{NaCl}$ on growth. In contrast the new isolates are clearly different from Thermus ruber.

All the Thermus strains found in Iceland so far have shown the same general characteristics originally described for the genus Thermus (Brock, 1984). The morphology and other characteristics of Thermomicrobium roseum are very different from those of Thermus (Table 1 and Jackson et al., 1973).

The new group of bacteria described in this paper is phenotypically very different from Thermus and other thermophilic and caldoactive bacteria (Table 1). Preliminary 16S rRNA sequence data furthermore indicate that it is phylogenetically distant from Thermus (Olafur $\mathrm{S}$. Andresson, personal communication). Based on all this we propose a new genus Rhodothermus for these bacteria. All the isolates belong to a single species, Rhodothermus marinus. Formal descriptions are given below.

Rhodothermus Alfredsson, Kristjansson, Hjörleifsdottir and Stetter, gen. nov.

Rho.do.ther'mus, Gr. n. rhodon rose; Gr. fem. n. therme heat; M.L. masc. n. Rhodothermus the red thermophile. Cells are Gram-negative, non-motile straight rods with curved ends, about 2$2.5 \mu \mathrm{m}$ long and $0.5 \mu \mathrm{m}$ wide, occurring singly. A slime capsule is formed on carbohydrate-rich medium. Colonies are reddish-coloured, low convex, 3-4 $\mathrm{mm}$ in diameter with an entire edge. Aerobic thermophilic neutrophilic heterotrophs. Growth strictly salt-dependent. Oxidase negative, catalase positive. No dissimilatory nitrate reduction and no casein hydrolysis. Growth on most common sugars like glucose, sucrose, and lactose but not on most amino acids. Cells are 
sensitive to penicillin, erythromycin, tetracycline and chloramphenicol, and resistant to streptomycin, kanamycin and gentamicin. The DNA base composition is about $65 \mathrm{~mol} \% \mathrm{GC}$.

The type species is Rhodothermus marinus, DSM 4252 (ATCC 43812).

Rhodothermus marinus Alfredsson, Kristjansson, Hjörleifsdottir and Stetter, sp. nov.

ma.ri'nus, L. masc. adj. marinus thriving in the sea, describing its biotope. Description as for the genus. Cells never occur in chains or filaments. Optimal growth at $65^{\circ} \mathrm{C}$ and pH 7 and about $2 \%(\mathrm{w} / \mathrm{v}) \mathrm{NaCl}$. Growth occurs at $6 \%(\mathrm{w} / \mathrm{v}) \mathrm{NaCl}$. The natural habitat is submarine alkaline hot springs.

The type strain is Rhodothermus marinus, DSM 4252 (ATCC 43812) (isolated from a submarine hot spring at Reykjanes, NW Iceland).

This work was supported by the Icelandic Science Foundation, the Research Fund of the University of Iceland, an equipment donation from the Alexander von Humboldt Foundation as well as by the Fonds der Chemischen Industrie to K.O.S. We thank Dr E. Degryse for a gift of strains, Johann Arnfinnsson, University of Iceland, for the electron microscopy, Dr W. P. Holbrook for critical reading of the manuscript, Gerta Lauerer for determining the DNA base composition and Olafur S. Andresson for information about the 16S rRNA sequence. We also thank Gudmundur O. Hreggvidsson and Sif Jonsdottir for assistance.

\section{REFERENCES}

Alfredsson, G. A., Baldursson, S. \& Kristjansson, J. K. (1985). Nutritional diversity among Thermus spp. isolated from Icelandic hot springs. Systematic and Applied Microbiology 6, 308-311.

BECKer, R. J. \& STARZYK, M. J. (1984). Morphology and rotund body formation in Thermus aquaticus. Microbios 41, 115-129.

Brock, T. D. (1978). Thermophilic Microorganisms and Life at High Temperatures. New York: Springer Verlag.

BRock, T. D. (1984). Genus Thermus Brock and Freeze 1969, 295 AL. In Bergey's Manual of Systematic Bacteriology, vol. 1, pp. 333-337. Edited by N. R. Krieg. Baltimore: Williams \& Wilkins.

BROCK, T. D. \& BRoCK, M. L. (1967). The measurement of chlorophyll, primary productivity, photophosphorylation, and macromolecules in benthic algal mats. Limnology and Oceanography 12, 600605 .

Corliss, J. B. \& Ballard, R. D. (1977). Oases of life in the cold abyss. National Geographic Magazine 152, 441-454.

Degryse, E., Glansdorff, N. \& Piérard, A. (1978). A comparative analysis of extreme thermophilic bacteria belonging to the genus Thermus. Archives of Microbiology 117, 189-196.

Egorova, L. A. \& Loginova, L. G. (1975). Distribution of extreme-thermophilic nonsporogenous bacteria in Tadzhikistan hot springs. Mikrobiologiya 44, 938-942.

Ericsson, J. L. E., Brunk, U. T. \& Arborgh, B. (1978). Fixation. In Electron Microscopy in Human Medicine, Instrumentation and Techniques, vol. 1, pp. 99-184. Edited by J. V. Johannessen. New York: McGraw-Hill.

Hayat, M. A. (1970). Principles and Techniques of Electron Microscopy. Biological Applications, vol. 1. New York: Van Nostrand Reinhold.

Hensel, R., Demharter, W., Kandler, O., KropPENSTEDT, R. M. \& STACKEBRANDT, E. (1986). Chemotaxonomic and molecular-genetic studies of the genus Thermus: evidence for a phylogenetic relationship of Thermus aquaticus and Thermus ruber to the genus Deinococcus. International Journal of Systematic Bacteriology 36, 444-453.

Hudson, J. A., Morgan, H. W. \& Daniel, R. M. (1986). A numerical classification of some Thermus isolates. Journal of General Microbiology 132, 531540.

Jackson, T. J., Ramaley, R. F. \& Meinschein, W. G. (1973). Thermomicrobium, a new genus of extremely thermophilic bacteria. International Journal of Systematic Bacteriology 23, 28-36.

JANNASCH, H. W. \& NELSON, D. C. (1984). Recent progress in the microbiology of hydrothermal vents. In Current Perspectives in Microbial Ecology, pp. 170176. Edited by M. J. Klug \& C. A. Reddy. Washington, DC: American Society for Microbiology.

Kristjansson, J. K. \& Alfredsson, G. A. (1983). Distribution of Thermus spp. in Icelandic hot springs and a thermal gradient. Applied and Environmental Microbiology 45, 1785-1789.

Kristjansson, J. K. \& Alfredsson, G. A. (1986). Life in Icelandic hot springs. Natturufraedingurinn 56, 4968 (in Icelandic with English summary).

KristJansson, J. K., Ingason, A. \& AlfredsSon, G. A. (1985). Isolation of thermophilic obligately autotrophic hydrogen-oxidizing bacteria, similar to Hydrogenobacter thermophilus, from Icelandic hot springs. Archives of Microbiology 140, 321-325.

Kristjansson, J. K., Hreggvidsson, G. O. \& AlFREDSSON, G. A. (1986). Isolation of halotolerant Thermus spp. from submarine hot springs in Iceland. Applied and Environmental Microbiology 52, 13131316.

KUSHNER, D. J. (1978). Life in high salt and solute concentration: halophilic bacteria. In Microbial Life in Extreme Environments, pp. 317-368. Edited by D. J. Kushner. London: Academic Press.

Lauerer, G., KRISTJansson, J. K., Langworthy, T. A., Konig, H. \& StetTer, K. O. (1986). Methanothermus sociabilis $\mathrm{sp}$. nov., a second species within 
the Methanothermaceae growing at $97^{\circ} \mathrm{C}$. Systematic and Applied Microbiology 8, 100-105.

Loginova, L. G. \& Egorova, L. A. (1975). An obligately thermophilic bacterium Thermus ruber from hot springs in Kamchatka. Mikrobiologiya 44, 661-665.

Loginova, L. G., Egorova, L. A., Golovacheva, R. S. \& Seregina, L. M. (1984). Thermus ruber sp. nov., nom. rev. International Journal of Systematic Bacteriology 34, 498-499.

MARMUR, J. \& DOTY, P. (1962). Determination of the base composition of deoxyribonucleic acid from its thermal denaturation temperature. Journal of Molecular Biology 5, 109-118.

Munster, M. J., MUNSTER, A. P., WoOdRow, J. R. \& SHARP, R. J. (1986). Isolation and preliminary taxonomic studies of Thermus strains isolated from Yellowstone National Park, USA. Journal of General Microbiology 132, 1677-1683.

Oshima, T. \& ImaHoRI, K. (1974). Description of Thermus thermophilus (Yoshida and Oshima) comb. nov., a nonsporulating thermophilic bacterium from a Japanese thermal spa. International Journal of Systematic Bacteriology 24, 102-112.
Pask-Hughes, R. A. \& Williams, R. A. D. (1977). Yellow-pigmented strains of Thermus spp. from Icelandic hot springs. Journal of General Microbiology 102, 375-383.

RAMALEY, R. F. \& Hixson, J. (1970). Isolation of a nonpigmented thermophilic bacterium similar to Thermus aquaticus. Journal of Bacteriology 103, 527-528.

RUSSELL, N. J. \& KoGUT, M. (1985). Haloadaptation: salt sensing and cell-envelope changes. Microbiological Sciences 2, 345-350.

StetTer, K. O. (1982). Ultrathin mycelia-forming organisms from submarine volcanic areas having an optimum growth temperature of $105^{\circ} \mathrm{C}$. Nature, London 300, 258-260.

STETTER, K. O. (1985). Thermophilic archaebacteria occurring in submarine hydrothermal areas. In Planetary Ecology, pp. $320-332$. Edited by D. E. Caldwell, J. A. Brierley \& C. L. Brierley. New York: Van Nostrand Reinhold.

Zillig, W., Stetter, K. O., Wunderl, S., Schulz, W., Priess, H. \& SCHOLz, I. (1980). The Sulfolobus'Caldariella' group: taxonomy on the basis of the structure of DNA-dependent RNA polymerases. Archives of Microbiology 125, 259-269. 